\title{
Retraction Note to: Air pollution detection in plain area based on web server and visualization of basketball training
}

\author{
Rong $\mathrm{Ji}^{1}$
}

Published online: 3 November 2021

C) Saudi Society for Geosciences 2021

Retraction Note to:Arabian Journal of Geosciences (2021) 14: 1533

https://doi.org/10.1007/s12517-021-07924-4

The Editor-in-Chief and the Publisher have retracted this article because the content of this article is nonsensical. The peer review process was not carried out in accordance with the Publisher's peer review policy. The author has not responded to correspondence regarding this retraction.

Publisher's note Springer Nature remains neutral with regard to jurisdictional claims in published maps and institutional affiliations.

The original article can be found online at https://doi.org/10.1007/ s12517-021-07924-4.

Rong Ji

rongji19802021@126.com

1 Shenyang Sport University, Shenyang, Liaoning, China 